\title{
APPLICABILITY OF REMOTE SENSING IN RESEARCH OF URBAN LANDUSE - MEDNARODNA DELAVNICA
}

Oddelek za geografijo Filozofske fakultete v Ljubljani je 16.6.2003 organiziral mednarodno medoddelčno delavnico $\mathrm{z}$ Inštitutom za geografijo in prostorsko planiranje z Univerze $\mathrm{v}$ Celovcu, z naslovom »Applicability of Remote Sensing in Research of Urban Landuse«.

$\mathrm{V}$ delavnici smo izmenjali poglede in izkušnje s področja uporabe daljinsko zaznanih podatkov za opredeljevanje rabe zemljišč na poseljenih, zlasti mestnih območjih, ter za spremljanje njenega spreminjanja. Celovški kolegi ( Mandl, Altziebler, Palencsar) so predstavili zbirko podatkov rabe in pokrovnosti tal Avstrije ter njihova iskanja - $\mathrm{z}$ vidika proučevanja mestne rabe tal - ustreznejših virov podatkov med satelitskimi in letalskimi sistemi za daljinsko zaznavanje, ter ustreznih metod za analizo tovrstnih podatkov. Gostitelji (Krevs) smo predstavili vire daljinsko zaznanih podatkov, ki jih uporabljamo v Sloveniji ter razmišljanja o njihovem čim učinkovitejšem povezovanju z obstoječimi državnimi evidencami, predvsem $v$ okviru raziskovalnih projektov $\gg$ Dinamika spreminjanja kategorij poselitvene rabe tal v Sloveniji v obdobju 1991-2002«, »Regionalna primerjava spreminjanja poselitvene rabe zemljišč med statističnimi regijami v Sloveniji v obdobju 1991-2002: po vzorčnih mestnih in suburbanih območjih«, CRP-a »(Ne)načrtno širjenje mestnega območja: izziv za trajnostni razvoj, urejanje in načrtovanje prostora « ter projekta 5 . okvirnega programa EU »Urbs Pandens«, ki jih vodimo ali sodelujemo pri njihovi izvedbi. Med glavnimi ugotovitvami v razpravi so bile naslednje:

- tradicionalni postopki spektralne klasifikacije po posameznih pikslih satelitskih posnetkov ne dajejo zadovoljivih rezultatov za potrebe proučevanja mestne rabe tal, predvsem zaradi kompleksnosti razmestitve in relativno majhnega prostorskega obsega posameznih kategorij rabe tal;

- ti tradicionalni postopki so problematični v analizah sodobnih večspektralnih daljinskih posnetkov visoke ločljivosti; nadomeščajo jih objektno usmerjene metode klasifikacije, ki temeljijo na segmentaciji daljinskih posnetkov;

- objektno usmerjene metode klasifikacije so "polavtomatske«, saj jih je potrebno izvajati z »učenjem« programa za klasifikacijo na podrobnih lokalnih podatkih; kljub izredno hitremu razvoju tovrstnih metod in orodij še vedno eno večjih težav predstavlja omejena prenosljivost lokalno »naučenih « parametrov in nastavitev klasifikacije na obsežnejša območja;

- dogovorili smo se o medsebojnem seznanjanju z novimi spoznanji s tega področja ter iskanju možnosti za raziskovalno sodelovanje.

$\mathrm{Na}$ delavnici so sodelovali geografi,ki se ukvarjajo z urbano geografijo in geoinformatiki z obeh ustanov ter dodiplomski in podiplomski študenti, skupaj 10 udeležencev.

Organizacijo delavnice je - kot strokovno oziroma znanstveno sodelovanje med partnerji iz Slovenije in Avstrije - finančno omogočilo Avstrijsko ministrstvo za izobraževanje, znanost in kulturo ter Avstrijski inštitut za Vzhodno in Jugovzhodno Evropo z Dunaja.

Marko Krevs 